Turtko Jakovina

\title{
Tito's Traitorous Clique, Kangaroos and Croats: The Australian Tour of the Football Club Hajduk and the Fight against the Cominformists in Oceania in 1949
}

\section{Cominformists Antipodeans}

"It is well known that the majority of Yugoslav emigrants in capitalist countries actively fought against the exploiters of the working class." This sentence was published in the Zagreb daily newspaper Vjesnik in late $1949 .{ }^{1}$ In Australia, Canada, the USA, Argentina, Uruguay, Chile, France, and New Zealand, Yugoslav emigrants often worked in the most difficult jobs. They were not well-connected, and they could hardly speak the languages of their new homelands, so many of them joined organizations that promised to help them. The leading Croatian newspaper of the time wrote, "The bourgeoisie of these countries felt that they had a great opponent in the workers of Yugoslav origin." In the most developed industrial countries to which they had moved, they often lived in terrible conditions, so in a world which was receptive to the ideas of the workers' movement, many of them became communists or leftists. In the first half of $20^{\text {th }}$ century, especially after the Second World War, the world was leaning to the left, and the Cold War intensified the divisions between the East and the Soviet Union on the one hand and the West on the other.

After the Resolution of the Information Bureau of the Communist Party of 28 June 1948 and the break of relations between the Soviet Union and the Federal People's Republic of Yugoslavia (FPRY), between Stalin and Tito, between the All-Union Communist Party (Bolsheviks) (VKP(b)) and the Communist Party of Yugoslavia (KPJ), the socialist world was divided. The split was a global one. Not only did all communist

1 Vjesnik, 12 November 1949. (Yugoslav expatriates join our Party's struggle). Majority of newspaper articles in Božidar Novak's collection are clippings. Therefore, it was not always possible to quote page numbers. 
parties have to choose their side, better say condemn Yugoslavia, but the lives of ordinary people were affected as well. The split was felt everywhere, including all emigrant associations, from New Zealand and Australia to Canada, Sweden and the United States. The split and the conflict between those who were for or against the countries of the People's Democracy and Stalin or Tito and FPRY was particularly noticeable in the United States, Canada, and Australia. The fact that the football club Hajduk had signed on a tour on the other side of the world lasting several months in the summer of 1949 made the division within the Yugoslavian community, and particularly Croats, more specifically Dalmatians, particularly prominent.

The first Croatian-Slavic society in Australia was founded in the west, in Boulder, in 1912, and it was "inspired by the hatred towards the Austro-Hungarian oppression." This was stated in the material prepared for Božo Novak, a journalist and politician, who led the delegation of the football club Hajduk from Split to Australia in the summer of 1949. A more substantial immigration of "our people", mostly Dalmatians, began after 1923 and the Great War. The immigrants were then taken advantage of by agents who would find them jobs - "the former Honorary Consul Nikola Marić, Jure Banović, and Andrejević and Niketić from Serbia", all of whom were "the core around which reactionaries gathered": "royalists, Greater Serbs, Greater Yugoslavs and Hun lovers." Joseph (Joe, Jozo) Alagich of Kotišina near Makarska, who took part in the Kotor mutiny in 1918, was the first to encourage Croats to celebrate Labour Day (1 May) in 1926 and to rally them around a leftist workers' platform. On 15 June 1928, the Militant Workers Movement was founded in the house of Petar Srzić, in which Jozo Alagich (Alagić), Šegedin and Ivan Viskich (Viskić) ${ }^{3}$ had the most prominent roles. Alagich was more of an anarchist than a communist, "and today he is neither - except a Cominformist," as stated by those who supported Tito in 1949. The Militant Workers Movement moved its headquarters to Sydney and was renamed the Yugoslav Immigrants Association in Australia. Although not all members were Croats, they, especially Dalmatians, did make up to $90 \%$ of the membership of the Association. ${ }^{4}$ They eventually decided to remove the hammer and sickle from the cover of the Association's periodical, which angered some of the more militant members, like Alagich, who wanted to continue to act conspiratorially, "secretly in forests or parks." It was only at the second congress in 1934 that a clearer course was set, so "comrade Kosović, the current Consul of the FPRY was elected secretary," and then work began "on a massive scale". During the war, there was unity. "We unmasked the 'legendary hero' Draža [Mihailović] and destroyed the dark clouds that spread among our emigrants." ${ }^{5}$ By 1948, the mobilization for moral 
and material help for the homeland was good, repatriation was on the way. Many of the emigrants wanted to return, but others began to appear, those dissatisfied with the outcome of the war.

In that period, the Association dominated the political life of Croats in Australia. According to the Yugoslav sources from the Consulate General in Sydney, there were only seven thousand Yugoslav emigrants in Australia. Half of them lived in Western Australia, mostly Perth. The majority of them worked in the gold fields, and a smaller part were in the desert, cut off from the settlements. "As if they had been cast out of the sky," they "cut the forest" for the mines. In Lakewood, emigrants lived the most primitive lives. "They have eaten plenty of flies and ants in their lives. They live in tents, they don't have water. They especially didn't have water previously, but they bought drinking water, so you can imagine how much water they bought for washing." In Warriewood near Sidney, in a bay sheltered from the winds, our people had become masters of tomato cultivation. "Good prices of their products are the greatest reason why that place has the most critics of Tito and 'his clique'- because they are afraid that the dispute will be resolved quickly and so they - the 'communists' - will have to go to their socialist homeland to build socialism."”

Hard living and working conditions, their exceptionally poor education, the fact that everyone had come from a similar area and that they shared similar fates, and then Tito's victory, the fact that many people in "the old country" and many of their relatives had been partisans, made Australian Croats very receptive to the ideas of the leadership of the Association, which were leftist or far-leftist. Even though they were divided into "royalists", "Catholics" and "simply anti-communists", a large number of emigrants, comprising 30 branches, supported Tito and the Russian Revolution. The periodical Napredak (Progress), whose first edition was first published in 1936, was banned from 1939 to 1942 for spreading communist propaganda, and thus it shared the fate of other non-English papers. However, it continued to be published. ${ }^{8}$ In 1947, Ivan Viskić became the secretary of the Main Board of the Association. By that time, a number of members of the leadership of the Association had changed. Some had died, some had returned to their homeland, others to the Consulate, so Viskić, who was present during that period, although he was not the most prominent member, had come to the fore. The first editor-in-chief of Napredak, Ivan Kosović, became the first consul of the post-war Yugoslavia. By the end of the Second World War, Macedonians living in Australia had established the organization "Edinstvo" (Unity) in Perth. "Edinstvo" was a member of the Yugoslav Immigrants Association in Australia, and after 1945 they formed the

Ibid.

Ibid.

8 Šutalo, Croatians in Australia, pp. 205-207; Lalić, Egzodus iz Australije u doba Hladnog rata, p. 79; Tkalčević, Hrvati u Australiji, p. 46. 
Macedonian League, remaining firmly connected with the YIAA. ${ }^{9}$ Macedonians, like Croats, left the country "when there was no freedom or justice there, when there was no bread or money there." 10

The feeling that after the war a new era would begin created the atmosphere that people should return from Australia. Optimism, faith in a better future and social justice made people return from France and the United States. They also returned from South America. In 1949, a fifth group of 149 emigrants returned to Dalmatia from Montevideo and Buenos Aires. They also returned after 1948 because "the truth about the just fight of the peoples of Yugoslavia against the revisionist and anti-Marxist actions of the USSR and the Cominform countries has been penetrating among our emigrants in Argentina, Uruguay, Chile, and other countries of South America."11 They also returned in large numbers from Australia aboard the ships Partizanka and Radnik - one seventh of them. Many of them wanted to join their families, to return after long years of absence. They spoke poor English, they did not think their children would ever be successful or become completely equal to other Australian citizens. They mostly moved in circles of people like them. ${ }^{12}$ Later, those who did not return to FPRY were described as "traitors," who "do not feel love for their homeland and who do not want to help her build socialism." 13

With the Resolution of the Communist Information Bureau on 28 June 1948, "traitors", "selfish opportunists", "headed by Ivan Viskić and Marin Kovačević, got ahead of themselves and aligned the Association with the Resolution." The Communist Party of Australia (CPA) initially condemned the "treachery of Tito's clique", although it did not seek to adopt the Resolution. This was done by the communists of Yugoslav origin, believing that Tito's clique could not remain in power for "more than a month or so, and thus they wanted to back the 'right' line." "Little Jozo cannot fight the great (Joseph)," spoke Marin Kovačević. "What Stalin says must go," said Marko Borić. "Socialism cannot be built with capitalists," wrote Marko Jelavić in Napredak. Indeed, Viskić demanded that the sentence stating that the Association had an obligation "to support the FPRY" be removed from the Statute of the Association. ${ }^{14}$ The sentence should read that they were obliged "to help the countries of the people's democracy," which no longer included the FPRY. It was exactly what Moscow was saying: Tito had become an Anglo-American spy, his government was using "gestapo-fascist" methods. ${ }^{15}$ Another reason why Viskić's views were this fervent was the fact that his relative Boro

9 Napredak, 5 November 1949. (They asked us to declare our trust to Tito; S. Srbinoff).

10 Center Tripalo, BN, Hajduk's tour of Australia.

11 Nova Jugoslavija, 12 January 1950, (Radnik comes to Split with a group of emigrants from South America).

12 Lalić, Egzodus iz Australije u doba Hladnog rata, pp. 82-123.

13 Vjesnik, 23 December 1949. (The truth about our struggle has come to Australia 2, Božidar Novak).

14 Vjesnik, 22 December 1949. (The truth about our struggle has come to Australia 1, Božidar Novak).

15 Naprijed, 11 November 1949. (Comrade Kardelj's speech to our emigrants in America). 
Viskić, former president of the local union council of Osijek, had been arrested. The "Titoists" had been holding him in prison for nine months, without "any arguments or courage to bring him to court, for they are surely afraid that he would unmask their dirty treacherous doings." ${ }^{16}$ In the Association, those "who were eager to insult the peoples of Yugoslavia, to belittle and undermine their National Liberation Movement" had prevailed. The Association had "stooped to counter-revolutionary, Trotskyist positions," and was purging non-sympathisers. ${ }^{17}$

In late 1949, the seventh national conference of the Yugoslav Immigrants Association in Australia was held, with delegates who had replaced "the best comrades", who had returned to the old country, and who were all "anti-Titoists". Instead of Tito, they pledged their loyalty to an "international communist movement led by the Soviet Union". They called all emigrants to a "fight against 'terror' in Yugoslavia". They organized rallies, seeking a mass condemnation of the government of Yugoslavia. According to reports in Yugoslavia, the rallies were poorly attended, but the new leadership of the Association still gained victory. The disgruntled members abandoned the Association, which worked in favour of the Cominformists. People in the Consulate believed that many of them were misguided, but the situation was serious because there was no strength to organize a counter strike. ${ }^{18}$ The Association was now held only by party members, but it has no support of the masses. These masses seem to be lost. They are still wavering and they don't know where to go, but with the passage of time they are becoming more convinced that the way of the Central Committee (CC) of the CPY is correct. However, many still do not approve of the conflict with the Soviet Union. "It would be wrong to say that such a weak response to the Association's leadership call is evidence that the people is behind us, who are in favour of the CC of the CPY. Even though in some places we do have the majority of active emigrants who have prevented that the resolution be sent, we still cannot claim that these people are in agreement with the policies of our Party and state leadership. Because if this were so, then we could organize the emigrants better and we could depose the leadership of the Association... However, in some places, we did succeed in sending supporting resolutions to Comrade Tito and our Government, etc., but it is nowhere near to what it should be and how we would like it to be."

Leading Cominformists (sometimes referred to in the Consulate as Informovci) in Australia were mostly members of the Communist Party of Australia. Many of them fought against the members of the Association for personal reasons. They were simply jealous of the former leaders who had positions in the Consulate and had until recently worked in similar jobs as they did. In every small and closed community, things are

16 Napredak, 27 August 1949. (The arrest of the chairman of the local union council of the City of Osijek).

17 Vjesnik, 22 December 1949. (The truth about our struggle has come to Australia, Božidar Novak).

18 Center Tripalo, BN, Information from Australia. 
always the same. ${ }^{19}$ The Resolution split the emigrants in the United States and Canada as well. Australian Macedonians also "voted no-confidence against Tito and the Yugoslav government". ${ }^{20}$ In early August 1949, the conference of the Macedonian League of New South Wales adopted a resolution stating that they regretted "that the nationalist leadership of the People's Republic of Macedonia - Koliševski, Vlahov - with Tito at the helm, led our people back to the bondage of reactionism and imperialism." ${ }^{21}$ They condemned Tito's policy towards Greece.

In New Zealand, there were about 6,000 Yugoslavs. They lived mostly on fishing and the production of resins and wine. The Yugoslav Club in Auckland had been in existence since the 1930s, but it was led by "royalists, Catholics or vulgar anti-communists", people without a clear political perspective, as stated in a report from the island. ${ }^{22}$ Savez jugoslavenskih iseljenika u Australiji (the Federation of Yugoslav Immigrants in Australia) was set up in 1942 in order to support the National Liberation Movement. Some of the members of the Savez, members of the Communist Party of New Zealand, took over the leading positions and tried to lead the association like a sectarian society, which was very difficult before 1948. The Main Board of the Savez had been divided for a long time, which led to inactivity of part of the membership, and then prominent members of the Savez, "super-Communists", launched the initiative to condemn the CC of the CPY. Thus in Auckland on 19 June 1949, "the Cominformists managed to push their Resolution," so the assembly of the Yugoslav society "Marshal Tito" also stood behind the Cominformists. ${ }^{23}$ They did it secretly, at assemblies where few emigrants were present. The interpretation of the Consulate General was that the disgruntled usually withdrew and became inactive. ${ }^{24}$ The difference in relation to Australia was that there were fewer emigrants, so the divisions were not as prominent, but the Yugoslav Alliance of New Zealand conformed to the Australians. 500 people were buying Napredak. "The Devastating work of the Cominformists" put a large number of emigrants off from the association, Vjesnik later reported. ${ }^{25}$

In other countries the situation was similar. Students from Yugoslavia, the "political emigrants in Bulgaria" set up a working brigade "Arso Jovanović", sending a clear

19 Šutalo, Croatians in Australia, p. 207; BN, information from Australia (13 typewritten pages).

In the material, rather detailed characteristics of 22 emigrant Cominformists were listed. Also listed were the names of 14 prominent emigrants "who are on our side".

20 Napredak, 5 November 1949. (They asked us to declare our trust to Tito; S. Srbinoff).

21 Napredak, 27 August 1949, A conference of a branch of the Macedonian League was held in NSW.

22 Center Tripalo, BN, A short report on the Yugoslav emigrants to New Zealand (4 typewritten pages).

23 Vijesti iz Nove Jugoslavije (The News from New Yugoslavia), no. 12, 12 August 1949, (Our emigration).

24 Slobodna Dalmacija, 16 September 1949; (A letter of one of our emigrants to New Zealand). Joze Pivac from Podgora, now in Feilding, New Zealand, wrote on 24 August 1949 that the number of traitors is small. Those who took over Napredak and took the traitors' side, were never true patriots. "Once they were patriots because it served their personal interest, and they were easily drawn to the side of those filthy liars today. (...) Be persistent and united - unity will prevail!"

25 Vjesnik, 23 December 1949. (The truth about our struggle has come to Australia, Božidar Novak). 
message that they were taking the side of Sofia and not of Belgrade. ${ }^{26}$ The Swedish-Yugoslav Society decided to sever "all ties with Tito's clique" on 15 August 1949, although Sweden, like all the countries of northern Europe, generally adopted a friendly stance towards Tito. This was well-received in Yugoslavia, as these were social democrats, so it was believed that co-operation would be better and easier with those who were at least somewhat ideologically close. Thus, the journalists of Napredak wrote that the Western media had until recently referred to Yugoslavia as a country with a "cruel Bolshevik dictatorship", and now it had become a "democracy", with Tito as a "hero" compared to Manerheim and Yugoslavia to the "poor little Finland".

After the Resolution, the Canadian South Slavic Association (Vijeće kanadskih Južnih Slavena, VKJS) and the editorial board of Jedinstvo (Unity) took the side of "the lies against Yugoslavia and its leadership without any arguments", "arbitrarily, without having convened a conference and without the approval of the membership." ${ }^{27}$ The accusations against Tito were untrue, what they were writing was against the workers, the information about the extensive Yugoslav trade with the West was false - the FPRY did not trade with the West any more than other nations of the people's democracy and the USSR. The proclamation said that Yugoslavia had not split from the "brotherly Slavic and socialist" states. Jedinstvo and the Canadian South Slavic Association argued that at the Third Convention 67 delegates and 17 representatives of the youth elected the Main Committee, which instantly lodged "a protest to Tito's government against terror and persecution of those who only wanted what was good for the people". ${ }^{28}$

In Yugoslavia, it was reported that all this was bad for the labour movement in Canada in general, especially for people coming from Yugoslavia. Progressive workers and genuine and honest patriots were not in favour of a destructive campaign against Yugoslavia because it would hamper the progress of "all Slavic socialist countries and destroy the unity of the workers' movement in the world." Emigrants were called on not to be afraid of standing with Yugoslavia and its creative potentials. They supported workers from Toronto and the members of the Canadian South Slavic Association in Noranda, Quebec. Tito had showed where he stood during the war, and now "he was building socialism, whether anybody liked it or not." This was how those who were on the Yugoslav side responded..$^{29}$ Both camps started rallying, those who protested against the enemy propaganda and those who thought that Tito was simply not in the right. Thus in the summer of 1949, the Social Club of the people of Sibenik in New York held a rally, so the Croatian Alliance in South Chicago adopted a statement attacking

26 Napredak, 20 August 1949. (The Paper of the Yugoslav emigrants to Australia and New Zealand; Arso Jovanović; The youth brigade of our students in Bulgaria).

27 Vjesnik, 12 July 1949. (The proclamation of Yugoslav emigrants to Canada).

28 Napredak, 6 August 1949. (A report from the convention of the Canadian South Slavic Association; resolution on the general work and tasks of the CSSA).

29 Vjesnik, 23 July 1949. (Emigrants from Noranda, Canada, condemn the anti-Yugoslav campaign). 
"certain people among our expatriates" who were on the side of the anti-Yugoslav campaign. ${ }^{30}$ In the United States and Argentina, some of the emigrants who sided with the Cominformists were expelled. Tomo Babin was expelled from the United States, just like the authorities of General Juan Perón in Argentina expelled ten leading members of the Slavic Association after the "Andersians and Titoists" attacked the association in early July 1949. ${ }^{31}$ In late July 1949 in Montevideo, the capital of the Eastern Republic of Uruguay, the Seventh Annual Convention of Slavic Societies was held. Eight Yugoslavs attended and proposed a resolution condemning Tito's government. Belgrade had joined the camp which was "hostile to the Slavs and the people's democracies," so they called for Yugoslavia to shift back. ${ }^{32}$

The struggle of societies and communists who ended up on opposite sides in relation to the Resolution of the Information Bureau was conducted through newspapers. In early October 1949 in the United States, the New Journal (Novi list) was started and was partly financed from Yugoslavia. This was done because the attacks that were coming from "the supporters of Pavelić, Nedić and Mihajlović" during the war were now coming from "some people who had been with us until recently". Now they "have changed, to their own and the people's detriment". ${ }^{33}$ As Napredak reported, New Zealand and Australia got a new periodical in "our language" in October 1950. Vijesti iz Nove Jugoslavije (The News from New Yugoslavia) was a biweekly newsletter. It was duplicated with a hectograph at first, before they moved on to printing. ${ }^{34}$ The paper, producing about 1500 copies, was edited "at the Consulate General in Sydney", the now rival Napredak reported. This was not a victory, but a "treachery, a further plunging in the mud of the working class and the struggle of the progressive humanity," a new form of spreading "Trotskyist and traitorous propaganda". It was all expensive and unnecessary, Napredak reported, but "material costs" were not a problem for the "traitorous clique, their masters in Belgrade". They did not regret "the millions they spent in their fight against the Soviet Union and the progressive movement in the world". ${ }^{35}$ What was happening now in the FPRY was worse than any occupation regime in this century, they reported. Traitors think they will break the Savez, Napredak, and the workers' movement, but "the emigrants will dismiss this treacherous rag and its editors, even if they printed it in golden letters!" They requested that their members send Nova Jugoslavija back.

The Consulate of the FPRY claimed that although Napredak was formally edited by Marin Kovačević, this was actually done by Viskić. In early 1950, it was reduced from

30 Slobodna Dalmacija, 4 September 1949, Sunday Review - Slander against the FPRY.

31 Napredak, 6 August 1949, The protest of the Main Board to the governments of the US and Argentina. The Andersians were Poles who supported General Władysłav Albert Anders.

32 Napredak, 27 August 1949, The Yugoslavs of Uruguay condemn the betrayal in our country.

33 New Journal, New York, October 12, 1949; Interview with Budimir Lončar 27 June 2018.

34 Center Tripalo, BN, information from Australia (13 typewritten pages).

35 Napredak, 15 October 1949, Limitless funds for the reactionary propaganda. 
twelve to eight pages, "which is important, because they have less space to print their falsehoods.” Božo Novak and his frequent interlocutor Luka Marković, who worked in the Consulate in Sydney commented that Napredak supporters had started to "back down a little." 36 That journal looked pathetic, they believed at the Consulate General. "Half of the journal just keeps slandering our socialist homeland, and the other half is filled with ads that keep this sorry excuse of a journal alive, a journal that had such a brilliant tradition and progressive background." Marković recommended that Nova Jugoslavija be better edited, that its design be more tasteful and technically better than that of Napredak. This did not mean that Nova Jugoslavija completely replaced the financially exhausted Napredak. "Don't say we have the people on our side. We don't," wrote Luka Marković from the Consulate in early February in 1950. Most of them didn't want to get involved, and two hundred of those who supported him, wrote the obviously realistic Marković, were largely members of the Party, so they still backed the "workers' journal". They were opportunists, cowards, they were committed to their friends.

The divisions that the Resolution of the Information Bureau brought were deep and far-reaching. It impacted not only international politics and the relations within the workers' movement and the socialist states of the time, but it also influenced the everyday lives of Yugoslav expatriates, many of whom didn't have a particularly close relationship with their homeland or were just ordinary citizens. They touched workers who produced resins in the north of New Zealand, maids in Buenos Aires, and stevedores in New York. For example, some more radical left-wing emigrants resented the fact that Alojzije Stepinac was given a mild punishment. Many were puzzled by the fact that after the war the Party continued to operate illegally, so they couldn't find its headquarters in the streets. They wondered how it was possible that all the communist parties were wrong, and only the CPY was right. Napredak, the only Yugoslav-Australian periodical, wrote that the propaganda of the "Tito-Ranković" machinery was gaining momentum, launching defamatory attacks on the USSR, and thus surpassing "the propaganda machine of the fascist regimes of Hitler, Franco, Mussolini and the ridiculous imperialistic liars in the USA and other capitalist states." ${ }^{37}$ Tito was handing over the industry and national wealth to capitalists. Many concessions were made to Italians, Austrians, the English and Americans. "The Yugoslav people are paying dearly for the 'help' of the West," and with its "hostile attitude towards the USSR, the FPRY has completely disconnected itself from co-operation with a socialist country, the protector and the liberator of our peoples." In "all emigrant colonies around the world" expatriates clearly "condemned Tito and his clique" and they remained on the side "of the progressive masses of our nation in the home country" who wanted to build "a true socialism". ${ }^{38}$

36 Center Tripalo, BN, A letter to B. Novak, 29 January 1950, Luka Marković.

37 Napredak, August 20,1949, (The peoples of Yugoslavia will always remain friends of the USSR).

38 Ibid. 
Emigrant associations, at least those who spoke openly in them, "vehemently condemned Tito's traitorous clique, which betrayed the achievements of the national liberation movement of our peoples, and has become the most prolific slanderer of the Soviet Union, the nations of the people's democracy and the progressive democratic order in all the world." ${ }^{39}$ As "an agent of the international reaction at the command of his imperialist masters,"Tito persecuted all those who wanted to remain "in the anti-imperialist front for peace and democracy." Thus S. Alagić warned that it was "a sacred duty to provide full assistance to the movement in Yugoslavia, which opposes the treachery of Tito's clique, and is fighting to save Yugoslavia for the front of peace, for socialism." This was why it was necessary to fight "against Tito's agents in this country" and their devastating propaganda. In New Zealand on 21 August 1949, Marin Ivičević explained that Napredak (Progress) could not be called as such if it wrote any differently about Yugoslavia. Exposing traitors, writing against the "traitorous leadership," but not the people, was the "duty" of editors and the association. ${ }^{40}$

"The Titoists are upset that the Democratic Workers' Movement calls Tito's regime in Yugoslavia fascist. But what else is it? The regime that persecutes, kills, imprisons and tortures sincere patriots who stood up and advocated co-operation and the unity of the workers' movement, who defended the Soviet Union as a supporter of socialism and world peace, who fought those who call the enslavement of the people 'socialism', what is that but fascism?", they asked as early as 1950, after the failed rally at which General Consul Vjekoslav Cvrlje spoke. The Committee of friends of the New Yugoslavia was defeated, because those who assembled voted for a resolution supporting the International Labour Movement and the Soviet Union in relation to the "Titoists," who were nothing more than "ordinary agents of imperialism and reactionism," and one demanding that "political prisoners... who are fighting against Tito's clique, and for socialism" be released, and that nations of the people's democracy co-operate. ${ }^{41}$ Could Tito see the truth, having fallen in the "mud of the dollar?"42

Thus, one year after the adoption of the Resolution of the Informburo, at the time of the largest mobilization in the home country, when Slobodna Dalmacija, as well as other newspapers in the FPRY, was full of news items about people gathering (narodni zborovi), the condemning of the Cominform countries, the strengthening of the unity of the people against the Cominformists or "against slander and disinformation", which was the title of a section in the central federal newspaper Borba (Struggle), the conflict was in full swing in the emigrants' rooms and clubs. As for its foreign policy,

39 Napredak, September 10, 1949 („Napredak sa priredbe u Warriewood“).

40 Ibid., (M.N. Ivičević on the importance of Napredak in NZ).

41 Napredak, July 1, 1950, A response from emigrants to the General Consul V. Cvrlje. A short report from the mass meeting in Sydney.

42 Napredak, 15 October 1949. (Athletes or Storm-troopers? Sinbad). 
the FPRY didn't change its course. It had already rejected the Marshall's plan, ${ }^{43}$ saying that the pressure from the US on the "Marshalized European countries" was growing. Washington intended to turn them into an open market for their goods. A "Bonn separatist state" had been created by American generals, and then the "West German puppet government", in which "Nazi magnates and other former Hitler's associates" participated. In America, the Ku Klux Klan was getting stronger, and there were reports about strikes in all Western countries. On the one hand, this was what the partners in the West were like, and on the other, there were no contacts with the former allies in the East. The crisis had to be internationalized, and this was happening because it was then that Edvard Kardelj, the Foreign Minister of the FPRY, managed to acquire the status of a non-permanent member of the UN Security Council for Yugoslavia. ${ }^{44}$ The Resolution of the Information Bureau in 1948 had become truly a global phenomenon. Survival could be defended by trying to convince others of one's own rectitude. This was also done in sports. The Belgrade football club Partizan toured Sweden in the summer of 1949, but the most important and longest was the three-month tour of the Split football club Hajduk in Australia.

\section{Hajduk's Australian tour. The Whites fighting the Red Koalas}

On 11 July 1949, Hajduk football players landed in Australia after a 42-hour flight. It was the beginning of the "most significant and interesting tour" in the history of the club, which lasted three months. ${ }^{45}$ No football club from Yugoslavia, with or without such a "great tradition and progressive background," had ever been on such a long journey (prior to 5 October 1949). ${ }^{46}$ Preparations for this tour had begun almost two years before the players left for Australia. The Main Board of the Federation of Yugoslav Immigrants in Australia (Savez) and Marin Alagić spoke with the leadership of the $\mathrm{Au}-$ stralian Football League at the request of the secretariat of Hajduk. The visit was seen as an opportunity which could contribute to the "rapprochement between our people and the locals." Hajduk was a symbol for most Dalmatians, especially men. ${ }^{47}$ Despite the unambiguous position of the Savez on the IB Resolution of 1948, Hajduk F.C. allowed the Savez to "represent them in this country," and maintained contact until two weeks before coming to Australia, Napredak reports. ${ }^{48}$ Before the arrival of the players,

43 Steil, The Marshall Plan, pp. 136, 148.

44 Jakovina, Američki komunisticki saveznik, pp. 286-288.

45 Center Tripalo, BN, Hajduk's tour of Australia (13 typewritten pages), Naprijed, 11 November 1949, The highest authority we obey is the will and the interests of the peoples of Yugoslavia. Hajduk's tour of Australia

46 Center Tripalo, BN, Report on the trip (handwritten calculation).

47 Napredak, 24 September 1949, Before the departure of the football team of Hajduk, how the trip came about and who made it possible.

48 Napredak, 12 November 1949, Something about Hajduk's latest attacks on the Savez. 
the Consul of the FRY in Sydney, Ivan Kosović, pulled a manoeuvre so that he could be the one to sign the contract, in an attempt to marginalize the Savez completely and use Hajduk "to spread Titoist propaganda among expatriates, and against our Savez and Napredak.”

According to Napredak, Božidar Novak reneged on the deal, defending Tito and attacking the Soviet Union and Napredak. In doing so, Novak was constantly "espousing Titoism". Thus, immediately after the arrival of the Split footballers in Australia, what could have been expected really did happen, just as the relations between the two groups deteriorated. This was happening everywhere. It was happening in Yugoslavia and also all around the world. The IB Resolution caused a rift in the world, and likewise among Yugoslav expatriates. "Already in the first contact with the emigrants, the treacherous and damaging doing of a handful of Cominformists became evident to us," Božidar Novak wrote in his report. ${ }^{49}$

"The whole of Yugoslavia is looking forward to your first performance. We are certain that you will represent the national sport of Tito's Yugoslavia with dignity. Warm regards to Hajduk." ${ }^{50}$ This was the first of many telegrams the players of Hajduk received on the way to Australia. The footballers were supposed to exhibit the strength of Yugoslav football and sports in general, "which bases its prosperity and development on the great care and assistance from our people's government." The level of football played by the Split club turned out to be first-rate. The players made "the impression of true socialist athletes," aware that they represented their "socialist homeland and a new movement in sports." Indeed, Hajduk demonstrated how sport was viewed in their "socialist homeland", in contrast to "how it is over there, where sport is closely linked to 'business' and where brutal exploitation of man by man is clearly evident." ${ }^{51}$ The footballers also charmed Australians with song. They were asked to sing at receptions and radio stations. It can be assumed that, in addition to partisan songs, they also sang Dalmatian klapa music. ${ }^{52}$ During the tour, 21 matches were played. Hajduk won 19 of them, lost one, and one was a draw.

Consul Ivan Kosović and the Consulate General staff organized a farewell party for the delegation and the footballers on their departure from Sydney on 12 September 1949. Hajduk "represented the sport of Tito's new Yugoslavia honourably," said expatriates "faithful to Tito's Yugoslavia." The farewell ceremony was held in a hall "adorned with the image of our people's most vile traitor, Marshal Tito," and below it was the

49 Center Tripalo, BN, Hajduk's tour of Australia (13 typewritten pages), Naprijed, 11 November 1949, The highest authority we obey is the will and the interests of the peoples of Yugoslavia. Hajduk's tour of Australia.

50 BN, International Telegram, 22 July 1949, Yugoslav Consulate General for Hajduk Sydney.

51 Slobodna Dalmacija, 29 October 1949. (We are returning to our homeland proud for we have carried out the task set by our Party and Tito, Vojko Andrijašević).

52 Slobodna Dalmacija, 9 September 1949. (From Hajduk's tour of Australia, Ivo Mrčić). 
"elite from the Consulate," Napredak reported. Novak attacked the USSR, Napredak and the Savez, and the representative of the Savez was not allowed to respond "to the vomit uttered by the said speakers." ${ }^{53}$ Novak told the emigrants that it was necessary to "always remain faithful to their homeland, especially today in the struggle that our country, led by the CC CPY and Comrade Tito, is fighting for equal relations between socialist countries and communist parties," Nova Jugoslavija wrote. "They called on Yugoslav emigrants to fight even more persistently against the traitors in the Napredak editorial board and the Savez, who slander and defame our country and its leadership for the interests of the Informburo. ${ }^{\$ 4}$

\section{Conclusion}

The IB Resolution was "a service to the bourgeoisie and the reactionaries," the unity of the international labour movement was shattered, part of Australian Croats wrote in Napredak. Actually, they were right, but they advocated an Stalinist course, an option for which it was better that it did not remain united and dominant. The "waverers among the emigrants" were impressed by the authority of the $\operatorname{VKP}(\mathrm{b})$, and they stood up against Yugoslavia, wrote those on the other side. There were many of them, even the official Yugoslav newspapers acknowledged this, but the bigger problem was that it was difficult to get them back to Tito's side. In 1949, Yugoslav newspapers reported that there were more and more of those who "saw the light," and realized where real socialism was being built, and the actual listing of the "right ones" - in Canada, Australia, France, America suggested how dramatic and serious the impact of the fight against the Cominformists on all continents was.

Hajduk's tour, which in any case would have had a patriotic charge, a propagandistic goal, the task of praising the Yugoslav authorities, had now been given an even clearer, more precise objective. It was necessary to try to show that the Yugoslav position was neither anti-socialist, nor anti-national, nor anti-labour, that Yugoslavia was not an enemy of the ideas under which it fought in the War, that it had not sold out. The staff of the Consulate General, who were known to everyone because they were emigrants themselves, sought to use Hajduk's tour to send messages of support for Tito and the Yugoslav leadership. So when they arrived at the celebration in Newcastle from the Consulate on 3 September 1949, they requested that "a resolution of confidence in the CC CPY, the Yugoslav government and Marshal Tito" be signed. The organizers, mostly Macedonians, declined to discuss politics, so they were attacked and accused of "fearing the truth... that they are worse than fascists." Božo Novak, who led the Hajduk

53 Naprijed, 11 November 1949. (The highest authority we obey is the will and the interests of the peoples of Yugoslavia. Farewell evening in Sydney).

54 Nova Jugoslavija, 18 September 1949 p. 1 (Expatriates say farewell to Hajduk). 
delegation in Australia, gave speeches, attacked Napredak and the Main Committee of the Savez..$^{55}$

The impact of the Cominform and the Tito-Stalin split was most deeply felt in Yugoslavia, and then among all Yugoslavs. Australian emigrants to Yugoslavia who had returned, as well as those from the United States or Canada, mostly advocated cooperation with Moscow, and after 1948 they found themselves in an embarrassing, almost bizarre situation. They returned from Yugoslavia to the countries they had left was partly because of dissatisfaction, disappointment, and the feeling that "US imperialists" still presented a real danger. Now, overnight, the protector of Yugoslavia and the working masses was supposed to be elsewhere. The IB Resolution undoubtedly weakened the Communist bloc, shattered the unity of Yugoslav communists and leftists, but it also demonstrated the ability of a small country to resist, get organized, become a factor and seize the historic opportunity for development it had never had, to gain the importance no Yugoslav society, at least three decades after the dissolution of the SFRY, would ever have again.

Hajduk's tour in Australia, not least because of their success on the football pitch, raised the reputation of both the country and Yugoslavs in Australia, at least for a short time. The success of the football players and the club, which carried such a high emotional charge for Dalmatians (especially having in mind their strong views on Tito which were demonstrated in Australia), shook those who had tried to separate Tito from Hajduk, and change current position of Yugoslavia. ${ }^{56}$ Savez, the Federation of Yugoslav Immigrants in Australia, was officially dissolved in 1960, by which time the political composition of Croatian emigrants to Australia had changed. The arrival of some of the supporters of the Ustasha movement or, to put it more mildly, those who disagreed with the communist Yugoslav leadership, even if it was anti-Soviet, changed the path of development of Australian Croats and other Yugoslavs. ${ }^{57}$ The split within the Savez and among older emigrants to Australia emboldened the Ustasha and Chetnik emigration and encouraged their faster organization. The strains within the community that persisted for years after the Resolution remain largely unknown. In Yugoslavia this topic was neglected in historiography since it represented a clear defeat of Tito's position in the struggle against Stalin, at least among the majority of Australians of Yugoslav decent. This topic has obviously not been interesting for emigration historians because it hardly fits into the stereotypical image of the model emigrant, nor could it subsequently be incorporated in any way into the turbo-nationalist narrative of "pure", "best", "successful” "proper" Croats as emigres have been represented ever since.

55 Nova Jugoslavija, 12 August 1949, p. 2 (From Hajduk's tour).

56 Vjesnik, 24 December 1949. (The truth about our struggle has come to Australia (Božidar Novak).

57 Sutalo, Croatians in Australia, p. 207. 


\section{Sources and literature}

\section{Archival sources}

Center for Law and Democracy „Miko Tripalo“, Zagreb (Center Tripalo), Personal Collection: Božidar Novak, (BN).

\section{Interviews}

\section{Budimir Lončar.}

Yugoslav Ambassador in Indoensia (1965-1969), Federal Republic of Germany (19731977) and the United States of America (1979-1983); Federal Secretary for Foreign Relations (1988-1991).

\section{Newspapers}

Borba, daily, Zagreb-Belgrade.

Napredak, List Jugoslavenskih iseljenika Australije i Nove Zelandije / The Only Jugoslav-Australian Newspaper, weekly, Sydney.

Naprijed, daily, Zagreb.

New Journal, weekly, New York.

Nova Jugoslavija, Bilten Ureda za informacije, Sydney.

Slobodna Dalmacija, daily, Split.

Vijesti iz Nove Jugoslavije, Sydney.

Vjesnik, daily, Zagreb.

\section{Literature}

Bezić-Filipović, Branka, Hajduk i iseljenici. Split: Hrvatska matica iseljenika, 2007.

Jakovina, Tvrtko, Američki komunistički saveznik. Hrvati, Titova Jugoslavija i Sjedinjene Američke Države 1945-1955. Zagreb: Srednja Europa/Profil, 2003.

Lalić, Vori, Egzodus iz Australije u doba Hladnog rata. Gordogan 19-22, zima - jesen 2010., pp. 66-126.

Marković, Luka, Pod australskim nebom. Zagreb: Izdavački zavod JAZU, 1973.

Steil, Benn, The Marshall Plan. Dawn of the Cold War. New York: Simon and Schuster, 2018.

Šutalo, Ilija, Croatians in Australia. Pioneers, Settlers and Their Descendants. Wakefield Press Kent Town, South Australia, 2004.

Tkalčević, Mato, Hrvati u Australiji. Zagreb: Nakladni zavod MH, 1992. 


\section{Summary}

\section{Turtko Jakovina}

\section{Tito's Traitorous Clique, Kangaroos and Croats: The Australian Tour of the Football Club Hajduk and the Fight against the Cominformists in Oceania in 1949}

The football club Hajduk from Split embarked on its longest and furthest foreign tour in the beginning of July 1949. The men of Hajduk went to Australia and New Zealand, where they were supposed to demonstrate the force of Yugoslav football and physical culture, although the real reasons were different. Members of the Australian Croatian community had come to Australia before the Second World War and were divided into "royalists", "Catholics", or simply "anti-Communists". A special problem was posed by those who were agitating "against the betrayal of Tito's clique". The paper will describe the tour of one of Croatia's and Yugoslavia's most famous football clubs, emphasizing the penetration of Cominform ideas within the Australian and New Zealand Croatian community, as well as Yugoslav attempts at opposing these ideas. 